Saudi Journal of Humanities and Social Sciences

Abbreviated Key Title: Saudi J Humanities Soc Sci

ISSN 2415-6256 (Print) | ISSN 2415-6248 (Online)

Scholars Middle East Publishers, Dubai, United Arab Emirate

Journal homepage: http://scholarsmepub.com/sjhss/

Original Research Article

\title{
An Analysis of Citizenship Education Teachers' Competence Based on Clinical Supervision
}

\author{
Zulaecha Ngiu*, Rasmon Baideng \\ Universitas Negeri Gorontalo, Indonesia
}

DOI: $10.36348 /$ sjhss.2020.v05i01.001

| Received: 19.12.2019 | Accepted: 26.12.2019 | Published: 11.01 .2020

*Corresponding author: Zulaecha Ngiu

\section{Abstract}

This study aims to analyze (1) the implementation of clinical supervision in developing competence of citizenship education teachers in a democratic perspective in junior high schools of Bulagi district, Banggai Islands Regency, Province of Central Sulawesi; (2) the contributing factors to the competence of citizenship education teachers by clinical supervision program for the school principals; and (3) the efforts undertaken in developing the teachers' competence. This study employs qualitative approach through case study. The data are generated from observation, interview, and documentation. The research comprises interactive data analysis to examine the data. The results show that (1) from the three phases of clinical supervision (the pre-observation meeting, observation of teaching process, and the evaluation), the effort of developing citizenship education teachers' competence was not optimally implemented; (2) there are three factors (teachers' educational background, teaching experience, and work ethic) which contributed to the non-optimal implementation of competence development of the teachers; (3) the school principals undertook stakeholder training, intensive lesson study, and classroom action research to improve the application of clinical supervision in developing competence of citizenship education teachers. It is for the teachers to achieve better competence.

Keywords: Competence, clinical supervision, teacher, pedagogiy, education, citizenship.

Copyright @ 2020: This is an open-access article distributed under the terms of the Creative Commons Attribution license which permits unrestricted use, distribution, and reproduction in any medium for non-commercial use (NonCommercial, or CC-BY-NC) provided the original author and source are credited.

\section{INTRODUCTION}

It is an obligation for teachers to possess professionalism as one of their core traits. Imron [1] states that a supervisor tends to act judgmental when supervising. In contrast, however, the actual concept of being a supervisor is to improve something (being clinical); given that, a supervisor is capable of transferring knowledge to the teachers, resulting in simultaneous improvement of weaknesses observed during a learning process. In particular, the essences of developing a supervision program are: (1) to develop a collegial relationship; (2) as a problem-solver; (3) to view supervision program as a shared need to improve the learning process. Moreover, Sahertian [2] mentions six techniques in performing clinical supervision, namely: (1) speak less, listen m Sahertian ore; (2) give comments to the teachers' statement; (3) clarify the teachers' question/statement; (4) acknowledge the teachers' performance and development; (5) avoid direct correction, instead, give some supports; and (6) recognize others' feeling. The observation conducted by the researchers indicates that the clinical supervision carried out by the school principals and supervisors was not optimally executed. This is on account of the teachers' perception that clinical supervision is similar to inspection; that the supervisors are trying to find fault with the teachers' performance during a learning process. It leaves teachers with more stress and less enthusiastic in a learning process, resulting in a lessattractive and monotonous style of teaching. The situation happened in junior high schools in Bulagi district, Banggai Islands regency, Central Sulawesi province. With that in mind, a comprehensive analysis is significant to address and solve the problems in schools in Bulagi district.

The observation conducted by the researchers in junior high schools in Bulagi district indicates that the learning process of citizenship education subject at the schools is far from effective. The condition is feared to impact the quality of teaching in the schools, due to the monotonous teaching style that lowers the students' enthusiasm in the learning process. Given that, this research attempts to solve the problem by encouraging for a democratic and humanistic clinical supervision program in junior high schools in Bulagi district. As being democratic, the supervision program enables the 
teachers to ask questions and give a response to the supervisor, ergo; it results in a mutual interaction between supervisors and educators.

This research undertakes clinical supervision for the reason (1) to address and solve the essential problems of the teachers; (2) to leave the learning process uninterrupted, since, in clinical supervision, the learning process keeps running as usual; (3) that the teachers can enhance their performance to address problems; and (4) to help teacher to arrange the appropriate learning experience in order for the students to possess basic knowledge and competence to improve themselves. By clinical supervision, it is expected to boost the teachers' performance, particularly regarding the learning process, for the supervisor democratically guides the teachers of their weaknesses.

The nature of intelligence should be shown as skill, determination, and successful actions. The nature of responsibility must be demonstrated as a truth of action either from the perspective of science, technology or ethics. Meanwhile, Syah [3] states that competence is a capability, skill, state of authority over something, and eligibility under the law. This is to say that competence is the core characteristic of a person which is related to effective performance and being superior in a particular job and situation. Furthermore, Sanjaya [4] argues that a competent teacher must be able to develop the three competence aspects, for example, personal competence, professional competence, and social competence. An effort of increasing teacher's competence needs to be programmed sustainably to achieve the expected output. There are four essential competencies for a teacher to possess, such as pedagogical competence, personal competence, professional competence, and social competence.

As asserted from Bafadal [5], clinical supervision is a form of practical application of teaching supervision, being significant to the educational development. Clinical supervision is designed as an approach to use when performing teaching supervision. Moreover, the supervisor needs a decent working climate when performing clinical supervision, as one key success factor of clinical supervision is that the teachers believe that the role of the supervisor is only to help them develop their teaching performance. On top of that, clinical supervision demands the monitoring and teachers to spare their time.

Pidarta [6] mentions that clinical supervision involves three steps, which include pre-observation meeting, teaching observation, and evaluation. In the pre-observation meeting, a supervisor needs to approach the teachers intimately and to be open to each other. During the meeting, teachers meet the supervisor to hand out the required files, for example, lesson syllabus, lesson plan, and learning material. In addition, the teachers consult the supervisor of aspects the teachers want to improve, to set the expected outcome further together. The notion echoes with Sergiovanni [7] who argues that the pre-observation meeting is conducted to build the intimacy between teachers and the supervisor, to identify aspects of performance the teachers need to develop, to transfer the teachers' affection into observable actions, to help the teachers to correct their aims by themselves, to set the time of class observation, and to clarify the learning context by considering the obtained data.

Furthermore, during teaching observation, the teachers actualize skills obtained from the previous step into teaching performance. Teacher's performance during learning process is observed by the supervisor by referring to observation instrument being prepared and agreed upon in the previous step. The notion is in line with Acheson and Gall [7] that there are several techniques of reviewing clinical supervision process, one of which is by using the checklist and timeline coding. Intimacy is maintained between the teacher and supervisor from the teaching observation until the class is over.

In the evaluation step, the supervisor needs to involve six vital steps, e.g. asking for the teacher's feeling/impression of the teaching performance; providing some reinforcements of the teacher's performance; analyzing the extent to which the teacher achieves the teaching objectives; analyzing to what extent the teacher has progressed in achieving the expected skills; concluding the observation result during the process of clinical supervision; encouraging the teacher to conduct further trainings; and planning further target [7]. Moreover, Sergiovanni [8] asserts that there are two targets of clinical supervision that this study highlights to reflect the multi-target of educational supervision, e.g. professional development and teacher's motivation and duty commitment. In the direct-oriented clinical supervision, the supervisor involves five actions, such as, clarifying and addressing the problems of teacher, providing solutions to the problems, demonstrating sample solutions of teacher's problems, setting the standard of problem-solving attempt, and giving feedback to the teachers when carrying out a given task [5].

Meanwhile, Beane and Apple [9] mention crucial features to improve in developing a more democratic school, such as (1) transparency of ideas, (2) growing trust between the individuals and groups with their competence to solve various issues in the school, (3) providing critical feedback in evaluating the school policy, various matters in the school, and attempts the school has undertaken to address the problems, (4) showing affection to other's well-being and public issues, (5) showing affection and awareness to selfesteem, individual rights, and minority rights, (6) 
sustainable development of democracy in the school, since the currently developed democracy is far from what is desired (7) an existence of a capable institution to continue to promote and develop democratic ways of life. Furthermore, Rosyada [10] points out that by the democratization of school management, one needs to encourage the responsibility of upgrading the quality of school principal and the teachers to improve the quality of education outcome.

Bafadal [5] once mentions that there are three contributing factors of teachers' competence in clinical supervision, namely:

\section{Teacher's Experience and Capability}

Suwaluyo [11] states that teaching experience is an extent of work period which refers to the number of teaching years. Also, Suwaluyo emphasizes that the duration of teaching experience show to which extent one has dedicated its life to teaching. When beginning their teaching career, teachers faced various supportive or hindering issues to overcome. As they progress, teachers will have to be able to adapt to different topics and therefore acquire more experiences to be referred when evaluating their performance. Moreover, Hamdani [12] suggests that "it is essential for a teacher to possess pedagogical and educational science background. Given that, one cannot consider that a teacher without the background can meet the teacher's competence standard." To be a teacher, one can learn from his/her experience, since there are particular issues in teaching only resolvable by skills acquired as the experience progressed, not from the teacher's formal background.

\section{Teacher's Motivation}

Hasibuan [13] points out that motivation involves how to enhance the employees' motivation to work more intensively to achieve the organization's objectives. On the other hand, Arifin [14] states that a leader needs to motivate the subordinates to (1) observe and understand the subordinates' behavior, (2) to determine the contributing factors of the subordinates' behavior, and (3) to consider, supervise, and to direct the subordinates' behavior. Moreover, Sergiovanni [15] proposes two basic assumptions to consider in clinical supervision, e.g. teaching process is a complex activity that needs extensive and precise observation and analysis, and a professional teacher prefers a more collegial method of improvement over an authoritarian method.

\section{Teacher's Work Ethic}

Djohar [16] defines teacher's work ethic as an actualization of a creative and measurable selfmanagement of teacher's performance. The features of an excellent work ethic are a well understanding of duties being performed, a capability to initiate a work without order, a fast-paced work tempo (to immediately shift to another project once a project is finished), decent time management, and a capability to enjoy work.

Sahertian [17] mentions three main models to increase teacher competence during clinical supervision, those are:

\section{Education and off-the-job training}

This involves individual or group training to enhance the teachers' competence and skills by stopping the learning process since it needs the teacher's full attention to achieve expected objectives. This is in line with Shoimin [18] who considers that the training can boost teacher's performance during the learning process. However, the teachers need to consider the frequency and intensity of off-the-job training to avoid lowering students' learning effectiveness. Moreover, Purwanto [19] asserts that there are several activities to conduct in the context of implementing supervision, i.e. holding a workshop, seminar, in-service training/upgrading, and to develop new teaching methods to improve the quality of learning process. Additionally, Widodo [26] argues that education and development are examples of the effort of acquiring better knowledge, skill mastery, and attitude of a teacher.

\section{Lesson Study}

Lesson study involves a group activity of teachers that evaluates and carries out a study on the lesson instruments designed by the teacher to create better mutual interaction among the teachers, therefore, resulting in more long-lasting implicit and explicit change in the learning atmosphere [20].

\section{Classroom Action Research}

Wardani [21] emphasizes that classroom action research is a form of self-reflection by teachers, students, or the principal to improve the practical values of education. Moreover, Arikunto [22] asserts that classroom action research is an action research performed by the teacher during the learning process in the class to enhance the quality of learning process.

\section{RESEARCH METHOD}

The study employs a qualitative approach in carrying out the research. The development of teachers' competence by clinical supervision in democratic perspective needs to be carried out in an integrative way; therefore, the qualitative approach enables the researchers to understand the whole context of the research site. The study engaged case study, in which it provides a detailed an in-depth description of a setting or an object. The case study involved setting the focus of development of the teachers" competence and interview to analyze the data. This is in line with Yin [23] who affirms that case study is conducted to answer the questions 'how and 'why' of the implementation of clinical supervision. The research took place at SMP Negeri 1 Bulagi, SMP 2 Bulagi, and SMP Satu Atap 
(one roof) Kombakomba; all are located in Bulagi district, Banggai Islands regency, province of Central Sulawesi. Moreover, the research engaged observation, interview, and library research to obtain the data.

\section{RESEARCH FINDINGS AND DISCUSSION Implementation of Clinical Supervision in Citizenship Education Teaching in Junior High Schools in Bulagi District Pre-Observation Meeting \\ During the interview, the researchers} discovered a gap between school principals in junior high schools in Bulagi district and the teachers. The principals performed supervision without informing the teacher to prepare the learning instruments needed for clinical supervision before the agenda. The principals seemed to be arrogant by suddenly giving the order to the teachers to be supervised just before the supervision began. The situation was due to the lack of intimacy between the principals and the teachers, and also the lack of cooperation between both sides to solve various issues during learning process together.

\section{Observation during Learning Process}

During the observation, the teacher showed indications of anxiety and insecurity when supervised. The situation was contrasted to the teacher's normal condition during the learning process, in which the teacher normally enjoys the learning process and the students are engaged in the process. Moreover, the principal of SMP Negeri 1 Bulagi discovered incoherence between the learning instruments and the teachers' actual performance. The principal noticed that the teachers lacked comprehension of learning material. The teachers also performed poor time management and preferred to use old-school teaching method rather than to apply a more attractive one with the help of learning media, such as laptop and LCD projector.

From an interview with the school principals, it indicates that clinical observation provides a significant contribution to the teachers, not only in solving issues in the learning process, but it also enables the teacher to develop their teaching skills and strategies.

\section{Evaluation}

As observed during the evaluation, the school principals informed to the teacher of missing aspects in the teachers' performance as mentioned previously. However, the principals did not provide further suggestion related to the aspects to assist the teachers. Moreover, the study noticed that the implementation of clinical supervision at SMP Satu Atap Kombakomba was far from effective since the implementation was not in accordance with the procedures set and did not meet the supervision objective. This problem was due to the lack of collaboration between the principals and the teachers to prepare for the supervision.
The previous result pointed out that the evaluation of the principals was not effectively conducted. As a supervisor, the principals did not develop a flexible atmosphere of intimacy with the teachers by being insensitive the teachers' feel during supervision and offering to listen to the teachers' problems during the learning process. Moreover, the teachers were not well-informed of the details in every step of supervision. The teacher also preferred conventional method (i.e. old-style lecture and material recitation) to a more cooperative and contextual method using learning media.

\section{Contributing Factors to the Development of Citizenship Education Teachers' Competence Teachers' Experience}

As observed during the supervision, most of the time the teachers did not prepare the required learning instruments systematically prior to beginning the learning process. It resulted in weak and monotonous learning activities for the students. Additionally, the observation found that the teachers' did not possess adequate skills in teaching method. The teachers also needed to enhance their abilities in developing attractive teaching methods, conducting a discussion among the teachers to address their performance issues and utilizing learning media to maximize their performance.

The observation highlighted that to achieve a maximum outcome; a teacher needs to design and prepare learning instruments thoroughly. This is to say that a teacher's appearance also matters to provide a decent role model for the students.

\section{Teachers' Motivation}

During the observation, the study discovered that the school principals did not provide an encouraging motivation to the teachers to enhance the teachers' performance. The principals only encouraged the teacher during the mid-term and final examination. Moreover, the extent of encouragement from the principals was unsatisfying, as the principals rarely provided feedback to the teachers' lesson instruments; the principals almost never monitored the teachers' attendance list and teaching schedule, and there was virtually no penalty for absent teachers. Consequently, the situation led to the teachers' ignorance of teaching duties. Furthermore, the lack of intimacy between the school principals and the teachers caused the teacher to show indications of distress. This is to say that the teachers still considered a supervisor as a judgmental inspector keen to find the teachers' slightest mistakes.

Therefore, it is deduced from the observation that teacher's motivation plays a significant role to the teacher's competence. Hence, it is essential for the teachers to develop the greater motivation to reach the expected learning objectives. 


\section{Teachers' Work Ethic}

The observation result revealed that the citizenship education teachers' work ethic was far from satisfaction. The teachers did not apply an effective teaching method and finished the class before the regulated time. Moreover, the teachers showed the poor responsibility of their duties. There was no motivation by the teachers to be punctual when the class begins. The teachers only communicated to the high-achievers and ignored the students with less capability to grasp the material. The teachers also did not attempt to improve their performance by engaging more attractive methods and consulting their teaching issues to the principal.

\section{Efforts of Improving the Competence of Citizenship Education Teachers \\ On-the-Job Training}

This study recommended the citizenship education teachers to attend various training to improve their competence. In this case, the school principal plays a major role in allowing the teachers to participate in events such as in-house training, workshop in regional and national level, meeting forums of citizenship education teachers, learning instrument design which refers to the Curriculum 2013. Moreover, it is recommended for the principals to provide scholarships for the teacher to continue their study to the higher degree to enhance their competence.

\section{Lesson Study}

This research discovered that the schools had conducted lesson studies previously. By lesson study, novice teachers can grasp significant information and experience, as they partake actively to give response and feedback during the activity. Moreover, in the lesson study, the teachers gather in the forum to discuss issues in the learning process, for instance, teaching methods and strategies, advanced learning media, and how to encourage students.

\section{Classroom Action Research}

The study uncovered the teachers have carried out and published classroom action research previously. The teachers also have implemented the results in teaching, in which the implementation succeeded to reach the expected output. In accordance with the implementation, the principals invited two tutors from the Office of Educational Affairs to conduct a workshop to the teachers with less information of classroom action research.

As extracted from the observation and interview, it is shown that events such as workshops, lesson study, and classroom action research provide a space for teachers to upgrade their competence, particularly in broadening their perspective to design more suitable teaching methods and strategies.

\section{DISCUSSION}

\section{Implementation of Clinical Supervision in Citizenship Education Teaching in Junior High Schools in Bulagi District Pre-Observation Meeting}

In the pre-observation meeting, the teachers consult the supervisor to hand out the required files of learning instruments. Also, the teachers consult the supervisor of aspects needed to be improved to set expected targets. The teachers and the supervisor further decided the next schedule of class observation. The notion echoes with Sergiovanni [7] who argues that the pre-observation meeting is conducted to build the intimacy between teachers and the supervisor, to identify aspects of performance the teachers need to develop, to transfer the teachers' affection into observable actions, to help the teachers to correct their aims by themselves, to set the time of class observation, and to clarify the learning context by considering the obtained data.

During the interview, the research discovered a gap between school principals in junior high schools in Bulagi district and the teachers. The situation was due to the lack of intimacy between the principals and the teachers, and also the lack of cooperation between both sides to solve various issues during learning process together.

\section{Observation during Learning Process}

The researchers observed the learning instruments and found out that the instruments were decently prepared, despite that some teachers did not update their lesson plan. During the observation, the teachers' performance throughout the learning process did not meet the expected objectives. By that, the teachers still need to strive maximally to enhance their competence. There are two essential assumptions for the supervisor to consider when conducting clinical supervision, i.e. teaching process is a complex activity that needs extensive and precise observation and analysis; and a professional teacher prefers a more collegial method of improvement to an authoritarian one. Clinical supervision is primarily a training of teachers' teaching performance. The implementation is designed practically and rationally, in which it is conducted based on data analysis of class activities. The context in which the supervisor and the teachers socialize is the basis for a procedural program and strategies for developing teachers' teaching performance [5]. It is deduced from the observation that the supervision was conducted not only for administrative preparation but also to calculate the extent of teachers' preparation of lesson plan and its implementation in the class.

\section{Evaluation}

The supervisor needs to perform an analysis of the addressed professional problems of the teachers to determine the vital issues and the contributing factors, 
to be further classified and solved one at a time. This is crucial to determine the extent of supervision result in developing the teachers' competence. Clinical supervision intends to address ineffective teaching patterns. Sergiovanni [8] mentions two targets of clinical supervision that echo the multi-target of educational supervision, i.e. professional development and teacher's motivation and duty commitment. During the evaluation, a supervisor is obliged to know the teachers' feeling after the class and henceforth, reinforce the teachers' motivation. Furthermore, the supervisor presents observation result in the form of raw and interpreted data. The supervisor further collects the teachers' feedback of observation result agreed upon previously. Afterward, the supervisor and the teachers collaborate to arrange further plans.

During the evaluation, the principals as the supervisors reported the result of clinical supervision on the citizenship education teachers of junior high schools in Bulagi district. The report addressed some problems the teachers faced and provided solutions regarding the issues. On top of that, the principals also reported any hindrance they faced during the implementation of clinical supervision. Along with the teachers, the principals concurred upon the demand of sustainable improvement of the implementation of clinical supervision in junior high schools in Bulagi district.

\section{Contributing Factors of the Development of the Citizenship Education Teacher's Competence Teacher's Experience and Skill}

Giving no rewards leads to the issue of students' engagement in the class. This happened in the citizenship education teacher's class. The high achievers were the only ones who participate a lot, and the other students seemed to be less enthusiastic. Consequently, certain skills are required for the citizenship education teacher in carrying out his or her duties and responsibilities during the process of teaching and learning. Teacher's educational background plays a major role in developing the teaching skill. By that, all the schools need to have qualified teachers for accomplishing the more demanding task and responsibilities. This notion is echoing the idea of human resource as a driving force by Nawawi [24]. In this concept, human resources refer to the workers, employees, or the personnel that has a potential to develop the organization further.

\section{Teacher's Motivation}

Based on the results, the citizenship education teacher seemed to be less motivated throughout the teaching activity. A poor social skill of the principal is believed to contribute to this problem. The tense situation, due to the gap between the principal and the teacher, during the supervision made the teacher suppressed. Therefore, rewarding and giving attention to teachers are among the duties of the principal. These aim at conceptualizing a successful learning in citizenship education subject. The observation results report that the supervision is still monotonous and somewhat authoritarian. An approach in supervision is necessary to identify and to develop teacher's professionalism, such as clinical supervision of teaching performance. According to Arifin [14], a leader is required to motivate his or her subordinates for the reasons as follows: 1) to observe and understand the behaviour of the subordinates; 2) to identify the contributing factors of the behaviour; and 3) to consider, to supervise, and to change the way the subordinates act. This is similar to the two notions of clinical supervision according to Sergiovani [15]. Firstly, teaching is complex that requires a keen observation and thorough analysis. The results of the observation and analysis allow a supervisor to develop teacher's capability during the learning and teaching activity. Secondly, professional teachers prefer a collegial approach to the authoritarian one.

\section{Teacher's Work Ethic}

The subject teachers tended to employ conventional teaching or lecturing to utilizing learning media. Moreover, the teachers did not give a chance to all students to participate actively in the class; the high achievers dominated the class, leaving the other students bored. The excessive use of a textbook also made the class ineffective. In other words, teachers were unable to design a better learning because of the lack of understanding the ideas of teacher's work ethics. Irmim and Rochim [25] argue that the work ethics of teachers are represented in 1). Teacher's readiness in preparing the lesson. 2). Teacher's punctuality. 3). Teacher's adjustment to rational targets. 4). Teacher's efficient work hours. 5). Responsibility towards the program. 6). Creativity and innovation. 7). Teacher's response to the unfavorable situation. 8). Consistency and consequent. 9). Willingness to learn and reading motivation. 10). Eagerness to write. In addition to the ideas by Irmim and Rochim, Djohar [16] explains teacher's work ethics as a conceptualisation of a creative self-management based on teacher's performances, such as understanding teacher's duties, able to work independently, effective time management, and feel empowered in teaching. All of the notions are not yet embedded in the citizenship education teachers in all junior high school in Bulangi district.

\section{Improving the Development of Citizenship Education Teacher Competence Teacher Education and Training}

The clinical supervision was conducted in all the junior high schools within Bulagi district. Following the supervision process, attempts such as explaining and discussing had been executed by the supervisor to provide a basic guideline to develop teachers' professionalism. The guideline consists of training, discussions, workshops, and related courses for the citizenship education teacher in either district or regional level. These programs involve individual and 
group activity to gain an in-depth understanding and skills for teaching. The teachers with more than 20work hours are allowed to attend the programs. Therefore, the programs listed can be regarded as an onthe-job training [18]. In addition, providing a scholarship for junior teachers and teachers might help to promote teacher's competence particularly junior high teachers in Bulagi district.

\section{Lesson Study}

Lesson study has the similar purpose with teacher training. Teachers will have themselves observed by their peers throughout the class. The observant take notes to the teachers' performance. To provide better feedback, the observant must be teaching a similar subject with the subject teachers. For instance, if the subject teacher teaches citizenship education the observant must teach this subject as well. Notes and feedback during the lesson study will be given to the subject teacher immediately. Understanding teaching competence allows the subject teacher to improve his or her instruction in the next class and thus to create a better learning atmosphere for students as well as improving school's achievement. Lesson study is a set of tasks and activities of teachers and students which are systematically designed by the teacher. Such a condition enables another teacher who acts as an observant to learn from and to interact with the subject teacher. The learning process leads to a continuous revision explicitly or implicitly [20]. The lesson study has been applied to citizenship education teachers of this research with one teacher act as a subject; the other will be the observant, and vice versa. This is to improve teachers' competence in managing the class, mastering the lesson, and how to act and interact with their teacher peers and the principal in the school.

\section{Classroom Action Research}

The skill of the citizenship education teachers had been developed by conducting a classroom action research. The results of the research will be in the form of scientific writing. Furthermore, the teachers can disseminate the insights and their experience from the research report through a seminar. The seminar allows teachers to build an interpersonal relationship with their peers. Information regarding various teaching approaches, classroom discourse, and identifying other aspects of social science is embedded in which allow teachers to have their competence developed.

The results of this research find some issues regarding the citizenship education teachers; each issue is different depends on the classroom situation. The issues revolve the application of certain approach or teaching method and its impact on the students' motivation or achievement. According to Wardani et al., [21], problems in a classroom action research reflect the situation of a school community including the teacher, student, and principal. From the outcome of the research, the society needs to improve their educational services. Arikunto [22] further adds that teachers conduct this type of action research to promote their teaching (method, approach, media, evaluation, and assessment). A classroom action research aims at finding a problem-solving method and encouraging research and innovations among the teachers.

The classroom action research can act as a supplement to the workshop and lesson study in terms of developing teachers' knowledge. In addition, these programs provide a space for teachers to think critically in determining the basis of teaching and learning according to the needs. It also helps teachers, especially the citizenship education teacher, to gain new experiences and to shape their competence.

\section{CONCLUSIONS AND RECOMMENDATION CONCLUSIONS}

The following are the conclusions based on the previous discussion:

- The supervision of the citizenship education teachers by principals in all junior high schools within Bulagi district is not effective. This is reflected in the three-stages of clinical supervision, namely the initial meeting, teaching observation, and the further meeting. From the democratic point of view, the principals as the supervisors were unable to execute the task due to a poor social skill. As a result, the teachers were reluctant to discuss their teaching with the supervisors.

- Factors that influence the development of teachers' competence, based on the democratic point of view in all junior high schools within Bulagi district, are: teachers' educational background, teaching experience, and work ethics. The citizenship education teachers need to consider these factors to develop their professionalism. This is because the principals had not supervised the teachers.

- The principals need to design a Program of developing teachers' competence to ensure that the clinical supervision will be continuously conducted. The program should be democraticoriented to bridge the gap between the teachers and the principals in all Bulagi district junior high school. Cooperating with related stakeholders is necessary to further gain information and knowledge for the citizenship education teachers in teaching. Conducting more intensive lesson studies and classroom action research are also essential.

\section{RECOMMENDATION}

The recommendations of this study are as follows:

- To shape teachers' professionalism, all the principals of junior high schools in Bulangi district are expected to supervise the teachers continuously. This is because teachers' performance affects students' achievement. In addition, it is suggested that principals need to conduct a need assessment. By that, schools will also gain benefit through quality teachers and students. Democratic values 
should be embedded throughout the supervision process to prevent the teachers being suppressed by the principal.

- The principals need to provide a space and give an equal chance for the citizenship education teacher to participate in training, workshops, and other forums in school, regional, and national level to broaden the teachers' insight. This also promotes creative and innovative learning in citizenship education subject, particularly in all junior high schools within Bulagi district.

\section{REFERENCES}

1. Imron, A. (2005). Supervisi Pendidikan dan Pengajaran: Konsep, Pendekatan, dan Penerapan Pembinaan Profesional, Malang: Universitas Negeri Malang.

2. Sahertian, P. A. (2008). Konsep Dasar dan Teknik Supervisi Pendidikan. Jakarta : Rineka Cipta.

3. Syah, M. (2003). Psikologi Belajar. Jakarta: PT. Raja Grafindo.

4. Sanjaya, W. (2008). Strategi Pembelajaran Berorientasi Standar Proses Pendidikan. Jakarta: Kencana Prenada Media Group

5. Bafadal, I. (2006). Peningkatan Profesionlisme Guru. Bandung: Bumi. Aksara.

6. Pidarta, M. (2004). Manajemen Pendidikan Indonesia. Jakarta: Rineka Cipta.

7. Makawimbang, J. (2013). Supervisi Klinis Teori \& Pengukurannya (Analisis di Bidang Pendidikan). Bandung: Alfabeta.

8. Sergiovanni, T. J. (2007). Supervision: Human Perspectives. New York: McGraw-Hill.

9. Beane. \& Apple. (1995). Education Democracy, Terh. Jakarta: Ditnaga Dirjen Dikti

10. Rosyada, D. (2004). Paradigma Pendidikan Demokratis. Jakarta : Kencana Prenadamedia group.

11. Suwaluyo. (1988). Pengalaman Mengajar Guru Profesional. Jakarta : Bumi Aksara

12. Hamdani. (2006). Rektuitmen Guru Demi Masa Depan Bangsa. Artikel

13. Hasibuan, M. (2008). Manajemen Sumber Daya Manusia, Bumi Aksara, Jakarta
14. Arifin. (2003). Kompetensi Guru dan Strategi Pengembangannya. Jakarta: Lilin Persada Press.

15. Sergiovanni, T. J. (1987). The principalship: A reflective practice perspective. Publication Sales, Allyn and Bacon, Longwood Division, 7 Wells Avenue, Newton, MA 02159 (Order No. H88511; \$34.95).

16. Djohar, M. S. (2006). Guru, Pendidikan dan Pembinaanya. Yogyakarta: Grafika Indah.

17. Sahertian, P. (2010). Perilaku Kepemimpinan Berorientasi Hubungan Dan Tugas Sebagai Anteseden Komitmen Organisasional, SelfEfficacy Dan Organizational Citizenship Behavior (OCB). Jurnal Manajemen Dan Kewirausahaan, 12(2), 156-169.

18. Shoimin, A. (2013). Excelent Teacher Meningkatkan Profesionalisme Guru Pasca Sertifikasi. Semarang: Dahara Prize.

19. Purwanto, M. N. (2012). Administrasi dan Supervisi Pendidikan, Bandung: Remaja Rosdakarya.

20. Shahabuddin, R., \& Zohir, M. (2003). Pedagogi: strategi dan teknik pembahasan pengajaran dengan berkesan. Shah Alam: PTS Publications \& Distributors Sdn Bhd.

21. Wardani, I. G. A. K., Wihardit. \& Nasoetion. (2004). Penelitian Tindakan Kelas Jakarta: Universitas Terbuka.

22. Arikunt \& Suharsimi. (2006). Penelitian Tindakan Kelas (Classroom Action Research-CAR). Penelitain Tindakan Kelas. Jakarta: PT. Bumi Aksara.

23. Yin, J., Hu, R., Chen, M., Tang, J., Li, F., Yang, Y., \& Chen, J. (2002). Effects of berberine on glucose metabolism in vitro. Metabolism-Clinical and Experimental, 51(11), 1439-1443.

24. Nawawi, H. (1998). Sumber Daya Manusia. Bumi Aksara, Jakarta.

25. Irmim dan Rochim, 2006, Administrasi dan Supervisi Pendidikan. Bandung: Jemmars.

26. Widodo, E. S. (2015). Manajemen Pengembagan Sumberdaya

Manusia. Pustaka Pelajar. Yogyakarta. 